\title{
Detection of Marek's disease virus meq gene in Feather follicle by Loop-mediated Isothermal Amplification
}

\author{
Ninad Sahebrao Lawhale ${ }^{1}$, Amarjit Singh ${ }^{2}$, Dipak Deka ${ }^{3}$, Ranvijay Singh ${ }^{4}$, \\ Ramneek Verma ${ }^{5}$ \\ 1,4 (Department of Veterinary Pathology, Guru Angad Dev Veterinary and Animal Sciences University, \\ Ludhiana, Punjab, India) \\ ${ }_{2}^{2}$ Animal Disease Research Centre, Guru Angad Dev Veterinary and Animal Sciences University, Ludhiana, \\ Punjab, India) \\ 3, 5 (School of Animal Biotechnology, Guru Angad Dev Veterinary and Animal Sciences University, Ludhiana, \\ Punjab, India)
}

\begin{abstract}
Marek's disease, caused by lymphotropic alphaherpesvirus, is one of the most economically significant diseases of poultry. Despite the ubiquitous use of vaccination to control losses, Marek's disease still affects poultry farming worldwide with an estimated annual loss up to US \$2 billion. There is a need for a simple and rapid diagnostic method for early detection of Marek's disease virus from clinical samples under field conditions. A loop-mediated isothermal amplification assay was developed using a set of six primers in order to detect meq gene segment of oncogenic Marek's disease virus (serotype-1) in feather tips of chickens. Bst polymerase was used for the isothermal amplification of viral DNA at $65^{\circ} \mathrm{C}$ for $60 \mathrm{~min}$ in a water bath. The fluorescence signal was identified in Marek's disease virus-positive samples after the addition of SYBR Green I under ultraviolet illumination. The loop-mediated isothermal amplification technique was found to be more sensitive as compared to Marek's disease virus-specific PCR for the detection of Marek's disease caused by oncogenic Marek's disease virus. The results demonstrate a significant advantage of loopmediated isothermal amplification in diagnosis of Marek's disease compared to conventional PCR as it can be carried out in most situations where rapid diagnosis is required, like in field conditions.
\end{abstract}

Keywords: Marek's disease, rapid detection, loop-mediated isothermal amplification, feather tips, poultry

\section{Introduction}

Marek's disease (MD) is a lymphoproliferative disease of chickens caused by cell-associated MD herpesvirus (MDV), a member of subfamily Alphaherpesvirinae of the family Herpesviridae and is characterized by multiple T-cell lymphoma formation in viscera, muscle, and skin as well as lesions in peripheral nervous tissues [1]. MDV strains have been classified into three serotypes that have major differences not only in the genome but also in the biological features. MDV is one of the most economically significant pathogens of poultry with an estimated annual loss up to US \$2 billion worldwide. MDV replicate productively in feather follicle epithelium cells and enveloped virions are shed. Being an assembly site for virus, feather contains massive amount of cell free virus [2]. The separation of Marek's disease virus genome directly from the bird without prior propagation in tissue cultures is possible. The Marek's disease viral genome from the feathers of infected chickens is six fold higher than from tumors making it advantageous for the separation of Marek's disease virus genome directly from the infected chicken [3]. Loop-mediated isothermal amplification (LAMP) method, amplify specific DNA sequences under isothermal conditions provided by a water bath and Bst polymerases, which have DNA strand displacement activity [4]. LAMP has been applied successfully for the detection of various human and animal viral pathogens. Recently, LAMP has been applied for the fast detection of MDV [5] and reticuloendotheliosis virus [6] from clinical samples. In India MDV-1 serotype has been reported and several genes of MDV have been identified among which the meq gene is specific to serotype 1 MDVs [7]. As Marek's disease still poses serious threat to the commercial poultry industry inspite of ubiquitous vaccination of the chickens, there is a need for a simple and rapid diagnostic method for detecting Marek's disease virus from clinical samples under field conditions. Hence, the present study was carried out to develop a diagnostic method based on the LAMP reaction for rapid detection of the MD viral genome in feather samples and to compare diagnostic efficiency of LAMP assay with conventional diagnostic PCR technique.

\section{Material And Methods}

2.1 Sampling: Feather follicles were collected randomly from live birds $(\mathrm{N}=30)$ from three different flocks. Flock-1, 2 and 3 comprised of RIR birds of 18-24 weeks, White Leghorn Layers of > 24 weeks and IBL80 broilers of $>24$ weeks of age, respectively. The bird in these flocks appeared apparently healthy but dead 
birds from these flocks, on necropsy, frequently showed the presence of tumours in visceral organs. From each flock, feathers were taken from 10 birds. Feathers were removed from neck and leg regions. Feather tips of 10$\mathrm{mm}$ containing feather pulp were further processed for DNA extraction.

2.2 DNA extraction: Feather tips with feather pulp were cut and mixed with $500 \mu$ lysis buffer (1M Tris HCL Ph 8.0, 5M NaCl, 0.5M EDTA, 10\% SDS) and $25 \mu$ Proteinase ' $\mathrm{K}$ ' $(20 \mathrm{mg} / \mathrm{ml})$ in sterile eppendorf tubes. The samples were incubated in water bath at $56^{\circ} \mathrm{C}$ overnight and DNA was extracted by phenol/chloroform extraction method as described by [5]. Concentration and purity of DNA was assessed by UV spectrophotometry using Nanodrop system (Nanodrop 2000C, Thermo Scientific, USA).

2.3 LAMP for $m e q$ gene of MDV: As the $m e q$ gene is present only in the serotype 1 (oncogenic MDV) of the MDV thus it was targeted as the main gene for LAMP reaction. The six primers as shown in Table 1 consisted of one pair of each outer primers (F3 and B3), inner primers (FIP and BIP), and loop primers (LF and RF) were designed [7] and synthesized by Integrated DNA Technologies, India. The LAMP reaction was carried out in $25 \mu \mathrm{l}$ reaction containing 10x Buffer, $25 \mathrm{mM} \mathrm{MgSO}$, 5 M Betaine, $10 \mathrm{mM}$ dNTP Mix , 10 pmol each of F3 and B3, 40 pmol each of FIP and BIP, 20 pmol each of LFP and LRP, and $4 \mu$ DNA template (50ng). The mixture was heated at $95^{\circ} \mathrm{C}$ for $5 \mathrm{~min}$, then chilled on ice, $8 \mathrm{U}$ Bst DNA polymerase (New England Biolabs) were added, incubated at $65^{\circ} \mathrm{C}$ for 60 minute in a water bath and heating at $80^{\circ} \mathrm{C}$ for 5 min to terminate the reaction. The LAMP products were analyzed by $2 \%$ agarose gel electrophoresis, under UV transillumination and naked-eye observation of a colour change after the addition of $0.5 \mu \mathrm{l}$ of SYBR green I dye (1000X) (Invitrogen).

2.4 MDV-specifc PCR for detection of oncogenic MDV: The primers for oncogenic MDV (M1/M2) were selected to amplify MDV-1 BamH1-H $132 \mathrm{bp}$ tandom repeats [8] producing an amplicon of $\sim 434 \mathrm{bp}$. The products were amplified using the primers M1/M2 shown in Table 2 as described previously [9]. The amplification was carried out in a $25 \mu \mathrm{l}$ PCR reaction containing $2.5 \mu \mathrm{l}$ of $10 \mathrm{X}$ PCR buffer $(-\mathrm{MgCl} 2), 1.5 \mathrm{mM}$ $\mathrm{MgCl} 2,200 \mu \mathrm{M}$ dNTPs, $25 \mathrm{pmol}$ of each primer and $1 \mathrm{U}$ of Taq polymerase. PCR parameters were: one cycle of initial denaturation at $94^{\circ} \mathrm{C}$ for $1 \mathrm{~min}, 31$ cycles of denaturation at $94^{\circ} \mathrm{C}$ for $1 \mathrm{~min}$, annealing at $55^{\circ} \mathrm{C}$ for $1 \mathrm{~min}$ and extension at $72^{\circ} \mathrm{C}$ for $1 \mathrm{~min}$, followed by a final elongation at $72^{\circ} \mathrm{C}$ for $10 \mathrm{~min}$. Electrophoresis was carried out in $1.5 \%$ agarose gel prepared using $0.5 \mathrm{X}$ TBE buffer containing $0.5 \mu \mathrm{g} / \mathrm{ml}$ ethidium bromide. Gene Ruler DNA $^{\mathrm{TM}}$ ladder 100bp plus (MBI, Fermentas) was run along with the test samples. Agarose gels were visualized under Geldoc (AlphaImager $3400 \mathrm{HP}$ ), photographed and analysed with the same software.

\section{Results And Discussion}

In the past, molecular techniques such as PCR and real-time PCR were developed for the diagnosis of MDV in DNA extracted from feather tips, lymphocytes or tissue samples from the infected chickens with the advantage that it could be used for both detection and differentiation between virulent and vaccine MDV [10; $11 ; 12]$. PCR assays usually take several hours to complete including electrophoresis time making it time consuming diagnostic method, a technique that requires a well-established laboratory, a thermal cycler and a gel system to visualize respective amplified products. The most important aspect of the present study was to diagnose and differentiate Marek's disease in a simple manner and in a more rapid way. Loopmediated isothermal amplification is a nucleic acid amplification method that synthesizes large amounts of DNA in a species specific-manner with high efficiency, speed and a low cost [4].

Feather follicles were collected from live birds $(\mathrm{N}=30)$ from three different flocks. The DNA was extracted from feather follicles and LAMP was applied for detection of meq gene of MDV-1. LAMP results were compared with MDV specific PCR carried out using M1 and M2 primers specifc for meq gene of MDV-1. The results are presented in Table 3. LAMP analysis showed 9, 10 and 10 DNA samples positive from flock-1 (Fig. 1), flock-2 (Fig. 2) and flock-3 (Fig. 3), respectively. MDV specific PCR detected meq gene of MDV-1 from 4, 6 and 7 feather follicle DNA samples of birds of flock-1, flock-2 and flock-3, respectively (Fig. 4).

The meq gene was selected as a target gene for LAMP analysis, as it is present only in the stereotype 1 of the MDV. The six primers consisted of one pair each of the outer primers (F3 and B3), inner primers (FIP and $\mathrm{BIP}$ ), and loop primers (LF and RF). The expected results in the present study were obtained at reaction temperature of $65^{\circ} \mathrm{C}$ at reaction time of 60 min with the loop primers. Without loop primers the LAMP reaction usually takes 90 minutes to amplify the target template [7]. Loop primers could accelerate the reaction because they hybridize to the stem-loops, except for those loops that are hybridized by the inner primers and prime strand displacement DNA synthesis [13]. The loop primers could also provide higher specificity, as the six primers could recognize the eight distinct regions of the target DNA [14].

MDV LAMP is approximately 100 -fold more sensitive than the conventional PCR when using the same template [15]. Similarly, [7] observed that the LAMP assay had a detection limit of 10 copies of the meq 
gene of serotype $1 \mathrm{MDV}$, whereas the PCR assay was able to detect 100 copies of the meq gene of MDV. The detection limit of the LAMP assay was 10-fold higher than that of conventional PCR. This sensitivity has also been depicted in the present study as LAMP successfully identified MDV in feather follicle samples from 29 birds out of 30 (96.66\%) as compared to 17 birds out of $30(56.66 \%)$ by MDV-specific PCR.

These findings demonstrate a significant advantage of LAMP in diagnosis of MDV compared either with PCR or virus isolation procedures as it can be carried out in most situations where rapid diagnosis is required, like in field conditions. A water bath or dry heating block is sufficient for DNA amplification because the method requires isothermal conditions. In addition, amplified LAMP products could be visualized by the addition of SYBR Green I dye without the need for gel electrophoresis; this makes it a very simple and cheap diagnostic tool. LAMP assays, therefore can generate results quickly in less well equipped laboratories or in field conditions.

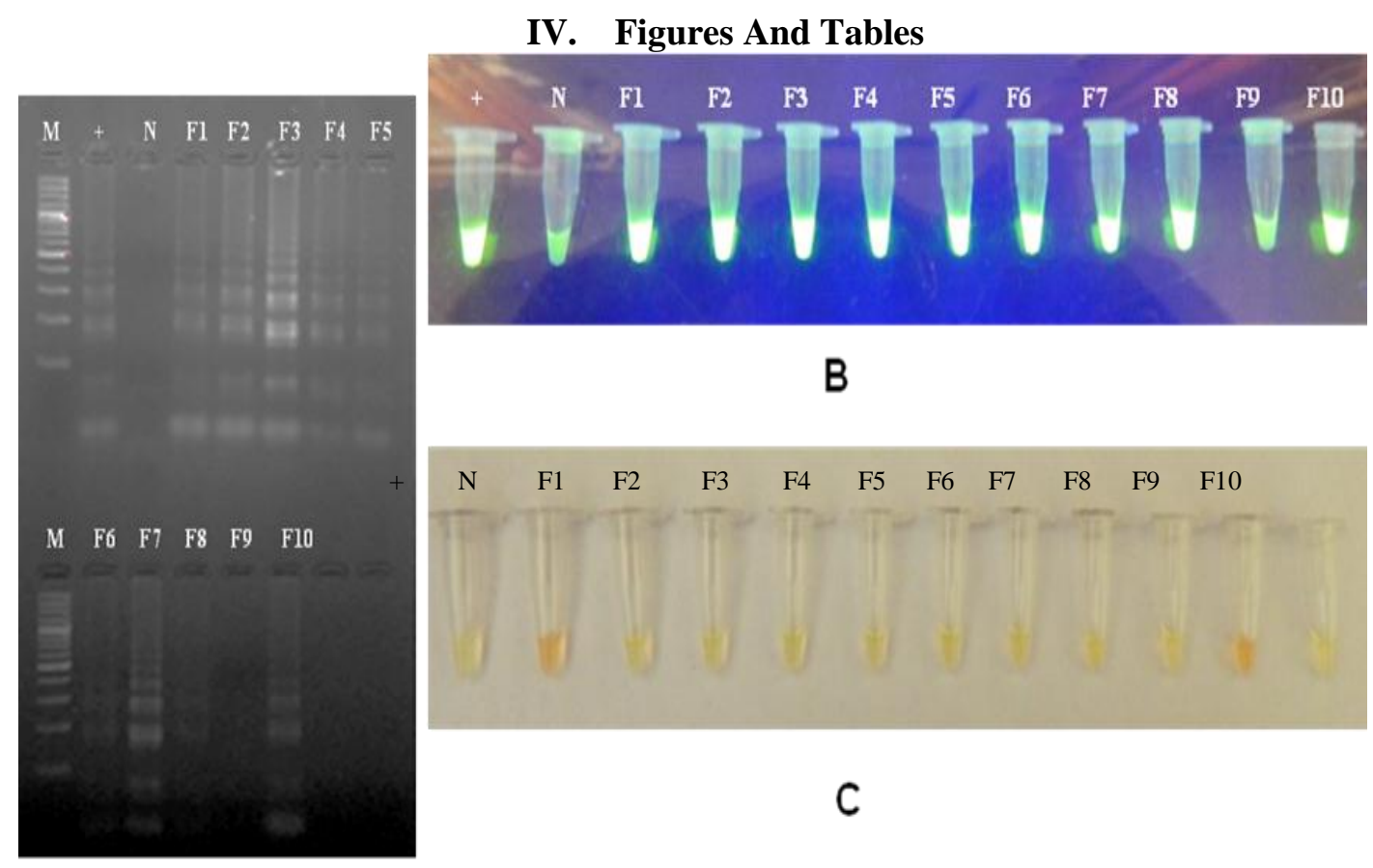

A

Fig.1 (A) LAMP amplified product of DNA samples from flock-1 (RIR birds), (B) LAMP products under UV transillumination and (C) Visual detection of LAMP products

Lane M :100bp plus Molecular weight marker, Lane N: Negative control, Lane +: Positive control, Lane 1 to 10: $\quad$ Samples

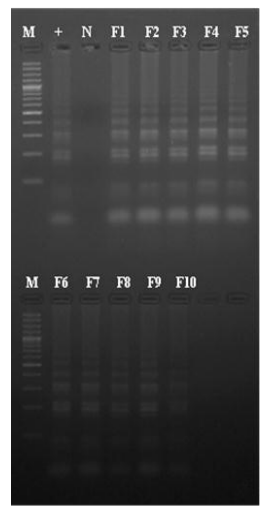

A

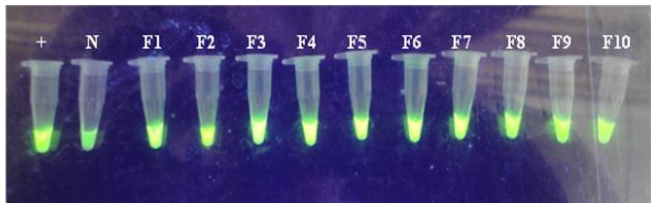

B

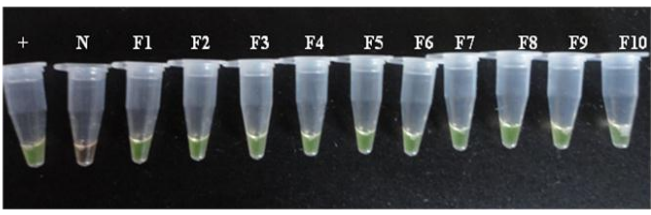

C

Fig.2 (A) LAMP amplified product of DNA samples from flock-2 (White Leghorn layers), (B) LAMP products under UV transillumination and (C) Visual detection of LAMP products

Lane M :100bp plus Molecular weight marker, Lane N: Negative control, Lane +: Positive control, Lane 1 to 10: $\quad$ Samples 


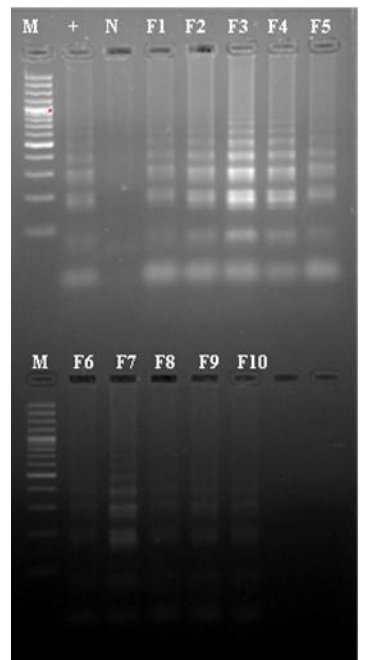

A

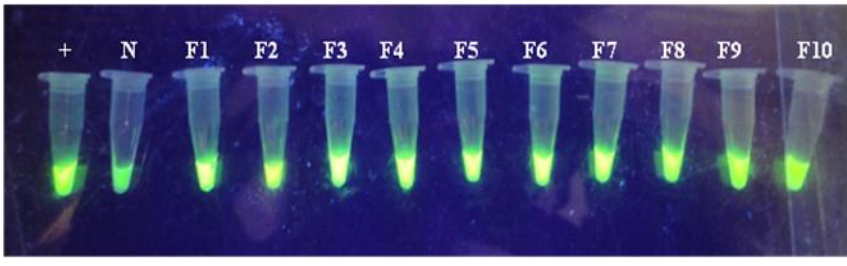

B

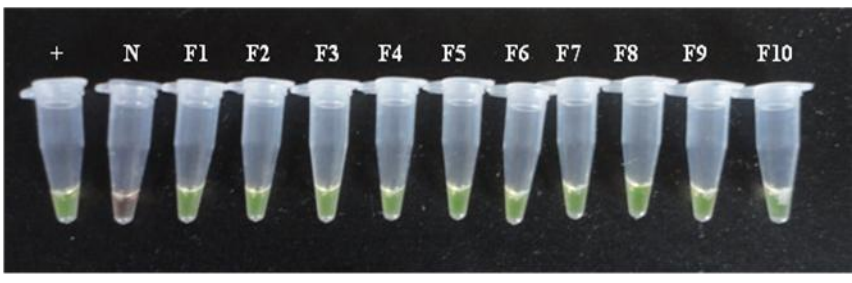

C

Fig.3 (A) LAMP amplified product of DNA samples from flock-3 (IBL-80 broilers), (B) LAMP products under UV transillumination and (C) Visual detection of LAMP products

Lane M :100bp plus Molecular weight marker, Lane N: Negative control, Lane +: Positive control, Lane 1 to 10: $\quad$ Samples

\section{Flock-1}

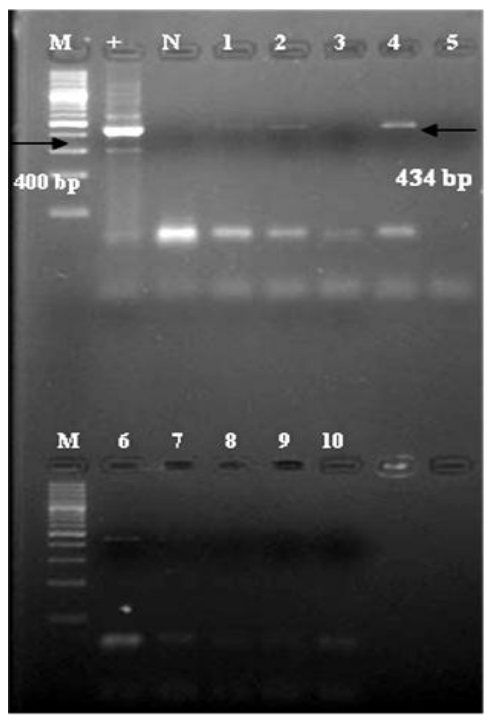

Flock-2

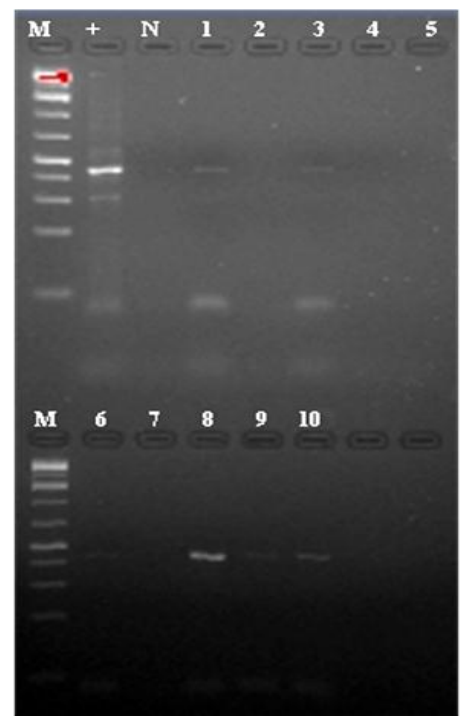

Flock-3

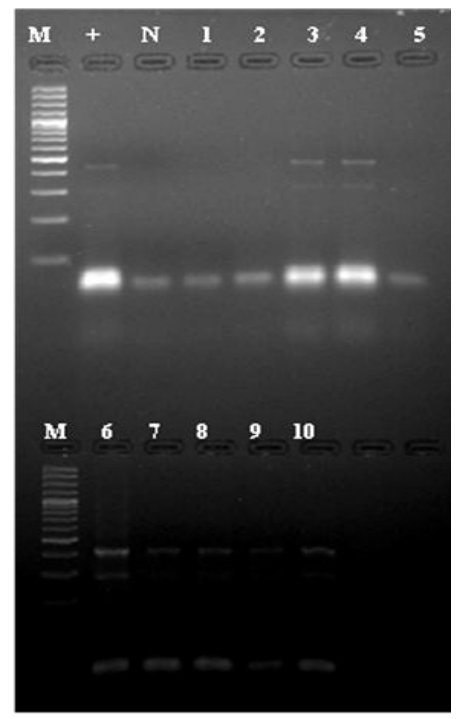

Fig.4 MDV-specific PCR amplification of DNA samples from feather follicles of live birds Lane M: 100bp plus Molecular weight marker, Lane N: Negative control, Lane +: Positive control, Lane 1 to 10: Samples

Table 1. Sequence of primers used for LAMP for the detection of $m e q$ gene of MDV-1 from feathers tips

\begin{tabular}{llc}
\hline Primer & Sequence $\left(\mathbf{5}^{\prime}-\mathbf{3}^{\prime}\right)$ & Primer size \\
\hline F3-MDV & CGT CCC TGC GTG TAC AGT & $18 \mathrm{bp}$ \\
B3-MDV & GGA ACC GGA GCA ATG TGG & $18 \mathrm{bp}$ \\
FIP-MDV & AGC AGT CCA AGG GTC ACC GTT TTT GGC TTG TCA TGA GCC AGT T & $43 \mathrm{bp}$ \\
BIP-MDV & CGC AGC ATC CCG TTC CTG AAT TTT GTT AGG TTC ATC CGG TGA GG & $44 \mathrm{bp}$ \\
LFP-MDV & GGT ACC GCC ATA GGG CA & $17 \mathrm{bp}$ \\
LRP-MDV & CCT CCC ATT TGC ACT CCT CC & $20 \mathrm{bp}$ \\
\hline
\end{tabular}

Table 2. Primers used for PCR amplification of MDV-1

\begin{tabular}{ccc}
\hline Primer & Sequence (5'-3') & Product size \\
\hline M1 & TAC TTC CTA TAT AGA TTG AGA CGT & 434bp \\
(Forward) & & \\
M2 & GAG ATC CTC GTA AGG TGT AAT ATA & \\
(Reverse) & &
\end{tabular}


Table 3. Detection of Marek's disease virus from feather follicles of live birds by LAMP and MDV-specifc PCR

\begin{tabular}{|c|c|c|c|c|c|c|c|c|c|}
\hline \multirow[t]{3}{*}{ Sr. No. } & \multicolumn{9}{|c|}{ Type of Bird } \\
\hline & \multicolumn{3}{|c|}{ Flock-1 (RIR birds) } & \multicolumn{3}{|c|}{ Flock-2 (White Leghorn Layers) } & \multicolumn{3}{|c|}{ Flock-3 (IBL-80 Broilers) } \\
\hline & Bird No. & $\begin{array}{c}\text { MDV- } \\
\text { specific PCR }\end{array}$ & $\begin{array}{l}\mathbf{L} \\
\mathbf{A} \\
\mathbf{M} \\
\mathbf{P}\end{array}$ & $\begin{array}{l}\text { Bird } \\
\text { No. }\end{array}$ & $\begin{array}{l}\text { MDV-specific } \\
\text { PCR }\end{array}$ & $\begin{array}{c}\mathbf{L} \\
\mathbf{A} \\
\mathbf{M} \\
\mathbf{P}\end{array}$ & $\begin{array}{l}\text { BirdN } \\
\text { o. }\end{array}$ & $\begin{array}{l}\text { MDV-specific } \\
\text { PCR }\end{array}$ & $\begin{array}{l}\mathbf{L} \\
\mathbf{A} \\
\mathbf{M} \\
\mathbf{P}\end{array}$ \\
\hline 1 & 1069 & + & + & 1107 & + & + & 3285 & - & + \\
\hline 2 & 800 & + & + & 1102 & - & + & 2539 & - & + \\
\hline 3 & 845 & - & + & 1140 & + & + & 3303 & + & + \\
\hline 4 & 957 & + & + & 1103 & - & + & 2109 & + & + \\
\hline 5 & 1051 & - & + & 1076 & - & + & 1691 & - & + \\
\hline 6 & 818 & + & + & 1111 & + & + & 2507 & + & + \\
\hline 7 & 781 & - & + & 1125 & - & + & 4042 & + & + \\
\hline 8 & 931 & - & + & 1144 & + & + & 4743 & + & + \\
\hline 9 & 917 & - & - & 1096 & + & + & 3396 & + & + \\
\hline 10 & 783 & - & + & 1114 & + & + & 3895 & + & + \\
\hline \multicolumn{2}{|c|}{ TOTAL } & 04 & 09 & & 06 & 10 & & 07 & 10 \\
\hline
\end{tabular}

\section{Conclusion}

MD-LAMP is a simple and timesaving procedure, allowing results to be obtained within 1 hour, whereas diagnostic PCR method typically requires 2 to 4 hours. When compared with diagnostic PCR specific for MDV1, MD LAMP was found to be more efficient as LAMP detected MDV in 29 out of 30 birds as only 14 out of 21 cases were found positive with diagnostic PCR. Considering the prevalence and economic impact of MD, the LAMP protocol described in this study represents a technique with the attributes that can be used under field conditions for the diagnosis or surveillance of serotype $1 \mathrm{MDV}$ infection. This technique has considerable potential for routine diagnosis in less-equipped laboratories, as well as under field conditions as it replaces an expensive thermocycler with that of a simple water bath. LAMP proved to be simple and rapid diagnostic method for detecting Marek's disease virus from clinical samples under field conditions. Hence, the present study was carried out to develop a diagnostic method based on the LAMP reaction for rapid detection of the MD viral genome in feather samples and to compare diagnostic efficiency of LAMP assay with conventional diagnostic PCR technique.

\section{Acknowledgements}

Authors are thankful to Dr. Raja Angamuthu, Department of Animal Biotechnology, Madras Veterinary College, Tamil Nadu Veterinary and Animal Sciences University, Chennai, Tamil Nadu, India for technical help in designing the primers for LAMP assay.

\section{References}

[1] R.L. Witter, K.A. Schat, Marek's Disease, in Y.M. Saif, H.J .Barnes, J.R. Glisson, A.M. Fadly, L.R. McDougall, D.E. Swayne (Ed), Diseases of Poultry, (Ames, Iowa State Press, 2003)407-465.

[2] B.W. Calnek, R.L. Witter, Marek's Disease in B.W. Calnek, H.J. Barnes, C.W. Beard (Ed) Diseases of Poultry, (Ames, Iowa State Press, 1997) 363-413.

[3] I Davidson, R. Borenshtain, The feather tips of commercial chickens are a favourable source of DNA for the amplification of Marek's disease virus and avian leukosis virus, Avian Pathol,31, 2002, 237-40.

[4] T Notomi, H. Okayama, H. Masubuchi, T. Yonekawa, K. Watanabe, N. Amino, T. Hase, Loop-mediated isothermal amplification of DNA, Nucleic Acids Res., 28(12), 2000, 63.

[5] G. Wozniakowski, E S. Salamonowicz, W. Kozdrun, Rapid detction of Marek's disease virus in feather follicles by loop-mediated amplification, Avian Dis., 55, 2011,462-67. 
[6] X Deng, X. Qi, Y. Gao, Y. Wang, L. Qin, H. Gao, L. Gao, X. Wang, Development of a loop mediated isothermal amplification method for rapid detection of reticuloendotheliosis virus, $J$ Virol Methods, 168, 2010, 82-86.

[7] R Angamuthu, S. Baskaran, D R. Gopal, J. Devarajan, K. Kathaperumal, Rapid detection of Marek's disease viral genome in chicken feathers by loop mediated isothermal amplification, J Clin Microbiol., 50, 2011, 961-65.

[8] I Davidson, R. Borenshtain, Multiple infections of chickens and turkeys with avian oncogenic viruses: Prevalence and molecular analysis, Acta Virol, 43, 1999, 136-42.

[9] N Mitra, R. Verma, A. Singh, Early detection of avian oncogenic viruses from blood of apparently healthy chickens, Proc Natl Acad Sci India Sect B Biol Sci, 2012, DOI 10.1007/s40011-012-0084-3.

[10] S J. Baigent, L P. Smith, R J. Currie, V. Nair, Replication kinetics of Marek's disease vaccine virus in feathers and lymphoid tissues using PCR and virus isolation, J Gen Virol 86, 2005, 2989-98.

[11] Y Becker, Y. Asher, E. Tabor, I. Davidson, M. Malkinson, Y. Weisman, Polymerase chain reaction for differentiation between pathogenic and non-pathogenic serotype 1 Marek's disease viruses (MDV) and vaccine viruses of MDV-serotypes 2 and 3, $J$ Virol Methods 40, 1992, 30722.

[12] K Krol, E. Samorek-Salamonowicz, W. Kozdrun, and G. Wozniakowski, Duplex PCR assay for detection and differentiation of pathogenic and vaccine strains serotype 1, Bull Vet Inst Pulawy, 51, 2007, 331-35.

[13] K Nagamine, T. Hase, T. Notomi, Accelerated reaction by loop-mediated isothernmal amplification using loop primers, Mol Cell Probes, 16, 2002, 223-29.

[14] M Parida, G. Posadas, S. Inoue, F. Hasebe, K. Morita, Real-time reverse transcription loop-mediated isothermal amplification for rapid detection of West Nile Virus, J Clin Microbiol., 42, 2004, 257-63.

[15] X Wei, X. Shi, Y. Zhao, J. Zhang, M. Wang, C. Liu, H. Cui, S. Hu, Y. Quan, H. Chen, Y. Wang, Development of a rapid and specific loop-mediated isothermal amplification detection method that targets Marek's disease virus meq gene, J Virol Methods, 183, 2012, 196-200. 